\title{
Protecting the Cameroon Elephant for Tourism Purpose - The Public Sector Role
}

\author{
Evaristus Nyong Abam, MSc* \\ Catholic University Institute of Buea, College of Business, Department of Tourism and Hospitality \\ Management, Cameroon
}

\begin{abstract}
*Corresponding Author: Evaristus Nyong Abam, Catholic University Institute of Buea, College of Business, Department of Tourism and Hospitality Management, Cameroon
\end{abstract}

\begin{abstract}
Saving elephants adds to the protection program as the threats to elephants evolve and tracking technology have been developed and which do not only tells us how fast elephants move through certain areas, often comparative to the perceived level of threat but it can also give us the exact positions of where families and vulnerable bulls are thus allowing concentration of effort. In environment where tourism and pastoralism are the two activities with the highest economic potential, communities have long had to grapple with retrogressive cultural practices like cattle rustling which bear down heavily on the security for people and wildlife thus reducing their prospects even. The lust for ivory and the situation in Africa have created what is likely to be the greatest percentage loss of elephants in history and there is fear that the survival of the species is at stake. For this reason zoo industry is starting to wake up and is beginning to develop more elephant-friendly environments. In an effort to stop the extinction of its elephant in particular and wildlife in general, the government of Cameroon protects itself against elephant poachers by sending the army to its national park and also deploying more Eco guards to its parks.
\end{abstract}

Keywords: Protection, Elephant, Elephant protection

\section{INTRODUCTION}

Most of the illegal ivory that is sold around the world comes from elephants that have been recently killed and this is not just coming from old stashes of ivory, but from elephants that have been poached within the last few years. Governments through their wildlife authorities used carbon dating to study hundreds of samples of ivory confiscated from around the world. In the past seven years, African elephant populations in savannahs have dropped $30 \%$ and similarly, the number of elephants living in forests has dropped incredibly by $62 \%$ from 2002 to 2013. As a result of this in 1989, the Convention on International Trade in Endangered Species (CITES) passed a moratorium on the international commercial trade of African elephant ivory, except under a few rare circumstances. In the same year, the Bush administration passed the African Elephant Conservation Act (AECA), banning the importation of ivory from the African elephant and since then, the commercial ivory market in the United States has virtually collapsed (www.mnn.com).

\subsection{Background of the Study}

Cameroon is a Central African country located on the Gulf of Guinea, between the 2nd and 13th degrees of north latitude and the 9th and 16th degrees east longitude. The country covers an area of 475,650 square kilometres. It has a triangular shape that stretches south to Lake Chad on nearly 1200 $\mathrm{km}$ away, while the base is spread from west to east $800 \mathrm{~km}$. It has south west a sea border of $420 \mathrm{~km}$ along the Atlantic Ocean. It is bounded to the west by Nigeria, to the south by Congo, Gabon and Equatorial Guinea, to the east by the Central African Republic and northeast by Chad. Finally, at the top of the triangle, north, it is headed by Lake Chad. The natural environment of Cameroon is diverse thus the saying 'Africa in miniature' (www.mintour.gov.cm).

The Ministry of Forests and Wildlife (MINFOF) has been entrusted with the management and monitoring of the Permanent Forest Estate (protected areas, communal and national forests); with the valuation of all forest and fauna resources and with the issue of peoples' access to those resources and/or to the benefits that are generated from it. It liaises with profit and non-profit organisations in 
the forestry sector and maintains the observance of international conventions ratified by Cameroon relating to wildlife and hunting. The Ministry is a co-chair of the national REDD steering committee together with the Ministry of Environment, Nature Protection and Sustainable Development. MINFOF is the main institution responsible for the implementation of the Forest and Environment Sector Programme (FESP). Largely through the FESP's basket fund, MINFOF receives technical capacity building and financial support to carry out its activities regarding forest monitoring. MINFOF is also currently developing and implementing the systems and measures required for FLEGT Voluntary Partnership Agreement (VPA) implementation (www.theredddesk.org).

\section{LITERATURE REVIEW}

Secure a future for elephants and to sustain the beauty and ecological integrity of the places they live; to promote man's delight in their intelligence and the diversity of their world, and to develop a tolerant relationship between the two species is a situation that African governments are grappling. Bring communities together to create safer conservancies where their animals, and wildlife, can live in peace. The first step to securing their areas is the deployment of community ranger (www.savetheelephants.org).

Thanks to domestic action and international support, we have seized over three tonnes of ivory and our intelligence suggests we have lost at least 10 times that much responsible for the safety of over $50 \%$ of the planets surviving forest elephants. Statistics made public by the Convention on International Trade in Endangered Species (CITES) demonstrated a significant increase in seizures of large hauls of ivory - a clear indication that sophisticated criminal organisations were moving more and more ivory around the planet (www.theguardian.com).

Elephant ivory fetches eleven hundred dollars a kilo on Asian markets and, in recent years IFAW has conducted anti-poaching and wildlife crime training in Cameroon and Chad, Kenya, Tanzania, Zambia, the Democratic Republic of the Congo, Congo-Brazzaville, India and Bhutan and they have also provided support for wildlife scouts, rangers and other anti-poaching patrols in many countries (www.ifaw.org).

\section{RESEARCH METHODOLOGY}

For this research work, the researcher used only secondary data that was information collected from the websites.

\section{ANALYSIS AND FINDINGS}

In February 2012, heavily armed poaching gangs from Sudan massacred more than $50 \%$ of the elephants in northern Cameroon's BoubaN'djida National Park. Large-scale elephant killings like the one witnessed in BoubaN'Djida can happen almost anywhere in the Region. While Faro National Park avoided the elephant massacre, financial and technical shortfalls not to mention its location near the border of Nigeria make this park extremely vulnerable to poachers and habitat destruction. In recent years, it has experienced increased poaching pressure and significant intrusion by pastoralists. While dedicated park staff is on the ground, they lack adequate support to carry out effective intervention and management. Conservation is no longer an issue for environmental institutions alone. People's lives and jobs are at risk because of it. Each time an elephant is killed a country is losing economic value. WWF is calling on Central African governments to put an end to ivory poaching and wildlife crime and during the world elephant day on Sunday, August 12, 2012. WWF (Worldwide fund for nature) fears that soon this event might celebrate an extinct species in Central Africa if ivory poaching and illegal wildlife trade is not ended. This incident, which drew worldwide media attention, Cameroon has moved to bolster security in its protected areas, including deploying 60 new Eco guards to secure BoubaN'Djida and monitor the park's remaining wildlife. While on a recent visit to the military training programme of the new rangers, Cameroon Forestry and Wildlife (MINFOF) Minister Ngole Philip Ngwese told the recruits "MINFOF is counting on you to fight the challenges on the field, especially with the massacre of elephants at BoubaN'Djida. Despite these efforts, elephant poaching in Africa has reached record levels in recent years, and Central Africa's unique forest elephants have been the hardest hit. Tens of thousands of elephants are killed each year for their ivory tusks, which are mostly trafficked to consumer markets in Asia (www.panda.org).

\subsection{Cameroon Protects itself Against Elephant Poachers by Sending the Army to its National Park.}

Faced with the threat of horse-mounted Sudanese elephant poachers armed with machine guns, the central African nation has deployed military helicopters and 600 soldiers to try to protect the park and 
its animals. Its decision to call in the army follows a bloody incursion into the park last winter during which poachers from Sudan killed some 300 elephants, or $80 \%$ of the park's elephant population, within a few weeks. Cameroon says it is determined to make sure such a scene is never repeated. Equipped with helicopters, night vision gear, and scores of jeeps, Cameroon's military has set up two garrisons in the park and several camps along Cameroon's border with Chad and the Central African Republic (www.nydailynews.com).

\subsection{Cameroon Deploys More Troops to Protect Wildlife.}

Cameroon is deploying more troops to protect the Lobeke National Park on its border with the Central African Republic (CAR) after a deadly attack earlier this month by armed poachers. The attackers fled back across the border into the CAR leaving behind carcasses of protected animals and tusks from at least 20 elephants, this park are being invaded by armed men from the neighbouring Central Africa Republic. According to him, the men were killing all animals they found and harvesting ivory from elephants this thus necessitate an agreement with the Ministry of Defence to deploy troops to protect the park. He added that the military will also train forest rangers to fight back when the invaders come, though there are no plans to arm the forest rangers. It is home to herds of forest elephants and lowland gorillas that conservationists warn may be wiped out if the current wave of poaching persists (www.voanews.com).

\subsection{African Wildlife Foundation will Provide Technical Assistance.}

At 3,300 square kilometres, Faro National Park is one of the largest parks in Cameroon and is home to significant numbers of elephant, Cameroon's largest population of hippopotamus as well as Lord Derby eland, roan antelope, giraffe, lion, leopard, and cheetah. To protect these species, AWF will strengthen existing counter-poaching forces, providing much-needed training and equipment. AWF will also help village and park guards integrate new ecological-monitoring procedures and technology into their patrols (www.awf.org).

\section{CONCLUSION}

The lust for ivory and the situation in Africa have created what is likely to be the greatest percentage loss of elephants in history and there is fear the survival of the species is at stake. African governments are very much busy working with international partners to save the elephants and other endangered species. In Cameroon, International efforts from organisations such the worldwide fund for nature (WWF), IFAW, World conservation society (WCS) have been notice in such areas as training, providing financial support and equipment's, organising seminars etc.

\section{REFERENCES}

[1] http://www.awf.org/projects/cameroon-elephant-anti-poaching [Accessed on 14/08/2017]

[2] http://www.ifaw.org/united-states/our-work/elephants/preventing-poaching [Accessed on 15/08/2017]

[3] http://www.mintour.gov.cm/en/presentation-of-cameroon/ [Accessed on 16/08/2017]

[4] https://www.mnn.com/earth-matters/animals/stories/6-ways-to-help-elephants [Accessed on 16/08/2017]

[5] http://www.nydailynews.com/news/world/cameroon-arms-elephant-poachers-calling-army-article1.1225884 [Accessed on 15/08/2017]

[6] http://www.panda.org/?205913/Cameroon-increases-elephant-protection-after-mass-slaughter [Accessed on $17 / 08 / 2017]$

[7] http://www.savetheelephants.org/project/anti-poaching/ [Accessed on 15/08/2017]

[8] https://www.theguardian.com/vulcan-partner-zone/2016/sep/23/cites-protect-elephants-poaching-ivory [Accessed on 17/08/2017]

[9] http://www.theredddesk.org/countries/actors/ministry-forests-and-wildlife-cameroon [Accessed on 18/08/ 2017]

[10] https://www.voanews.com/a/cameroon-wildlife-poaching/3637335.html [Accessed on 18/08/2017]

Citation: Evaristus Nyong Abam. "Protecting the Cameroon Elephant for Tourism Purpose - The Public Sector Role". International Journal of Research in Tourism and Hospitality (IJRTH), vol 4, no. 1, 2018, pp. 18-20. doi:http://dx.doi.org/10.20431/2455-0043.0402002.

Copyright: (C) 2018 Authors. This is an open-access article distributed under the terms of the Creative Commons Attribution License, which permits unrestricted use, distribution, and reproduction in any medium, provided the original author and source are credited. 